\title{
Are private and social goals aligned in pasture-based dairy production?
}

\author{
Craig Galloway ${ }^{\mathrm{a}, ~ *}$, Beatrice Conradie ${ }^{\mathrm{b}}$, Heidi Prozesky ${ }^{\mathrm{c}, \mathrm{d}}$, Karen Esler ${ }^{\mathrm{a}, \mathrm{e}}$ \\ a Department of Conservation Ecology and Entomology, Stellenbosch University, Private Bag X1, Matieland 7602, South Africa \\ b School of Economics and Centre for Social Science Research, University of Cape Town, Private Bag X1, Rhodes Gift 7703, South Africa \\ ${ }^{\mathrm{c}}$ Centre for Research on Evaluation, Science and Technology, Stellenbosch University, Private Bag X1, Matieland 7602, South Africa \\ ${ }^{\mathrm{d}}$ DST-NRF Centre of Excellence in Scientometrics and STI Policy, Stellenbosch University, Private Bag X1, Matieland 7602, South Africa \\ e Centre for Invasion Biology, Stellenbosch University, Private Bag X1, Matieland 7602, South Africa
}

\section{A R T I C L E I N F O}

\section{Article history:}

Available online 6 December 2017

\section{Keywords:}

Sustainability

Environmental impact

Total factor productivity

Pasture-based dairy

\begin{abstract}
A B S T R A C T
To become more sustainable, dairy farms should aim to maximise productivity at a minimum cost to the environment. Standard environmental impact measures were combined with non-parametric total factor productivity analysis to investigate if this is possible in a pasture-based production system. Stocking density and energy-corrected milk production per hectare correlated with overall farm efficiency. More effective use of concentrates and farm-produced hay make these operations more productive and at the same time lower their carbon footprint and make them more nutrient-use efficient. Therefore the pursuit of greater sustainability is well aligned with the objective of profit maximization in this relatively clean form of dairy production.
\end{abstract}

() 2017 Elsevier Ltd. All rights reserved.

\section{Introduction}

In a finite resource world, agriculture will have to become more sustainable if it is to cope with ongoing income and population growth. However, the complexity of the biophysical system that needs to be made more sustainable has thus far prevented meaningful measurement of progress (Mayberry et al., 2005; Ernst and Wallace, 2008; McGuire et al., 2013). There is some consensus that it is desirable to look at multiple dimensions of sustainability at the same time (Rigby et al., 2001; Van Calker et al., 2005; Bezlepkina et al., 2011; Salazar-Ordonez et al., 2013). For dairy farming, the sustainable production problem can be formulated as minimising the environmental impact of a given level of milk production or maximising the output associated with a given level of environmental impact. This paper takes the second approach and uses total factor productivity (TFP) analysis as its main theoretical frame. In this approach, the technical efficiency with which all inputs are converted into all outputs are considered. The two main environmental impacts considered are nutrient and greenhouse gas emissions.

TFP analysis can be approached parametrically or nonparametrically. On the parametric side, a stochastic frontier with

\footnotetext{
* Corresponding author

E-mail address: craig@traceandsave.com (C. Galloway).
}

inefficiency effects has been the standard formulation in the field since Battese and Coelli (1995) and models of this kind have been applied to dairy production many times (e.g. Hadley, 2006; Mkhabela, 2006; Reinhard et al., 1999). See Coelli et al. (2005) for a technical description of how these models work. This class of model involves establishing best practice to measure firm-level inefficiencies and then explaining those inefficiencies with observable data. In early applications, separate models were run in which the distributional assumptions needed to predict inefficiencies contradicted those needed to explain them. In the Battese and Coelli (1995) formulation this problem is avoided by fitting both sets of parameters simultaneously.

A nitrogen surplus as possible explanation of deviations in farmlevel efficiency first appeared in the translog production function put forward by Reinhard et al. (1999). Later a phosphate surplus and total energy use were added to the model, which was used to calculate environmental efficiency using both stochastic frontier analysis and data envelopment analysis (Reinhard et al., 2000). Unlike stochastic frontier analysis, data envelopment analysis (DEA), the standard non-parametric approach, accommodates multiple outputs of which one is often formulated as an environmental "bad". Ramilian et al. (2011) incorporated nitrogen discharge as an undesirable by-product of milk production, Iribarren et al. (2011) included waste water and air pollutants and 
Toma et al. (2013) considered the effect of greenhouse gas emissions, nitrogen surplus and phosphorous surplus on dairy production.

Our study asks if high levels of technical efficiency in dairy production are associated with high or low levels of nutrient and carbon emissions. Like Reinhard et al. (2000) and Toma et al. (2013) we examine both greenhouse gas emissions and nitrogen and phosphorus surpluses. The argument goes as follows: if an increasing productivity (or economic efficiency) is associated with increasing levels of $\mathrm{CO}_{2}$ or nutrient emissions, a trade-off between economic and environmental objectives will be confirmed; but if productivity and emission levels are negatively associated, emission reductions will be a by-product of profit maximisation.

\section{Material and methods}

\subsection{Dataset}

The dataset used in this analysis was obtained from Woodlands Dairy's Sustainability Project. Woodlands Dairy is a private milk processor and manufacturer of dairy products based in Humansdorp in the Eastern Cape Province of South Africa. The Sustainability Project runs the Trace \& Save Programme which is aimed at cost effectiveness and limiting environmental impact. The program monitors milk, feed and fertilizer data as well as the soil and water data needed for carbon footprint and nutrient budget analyses and offers a field advisory service to producers. Producers receive a monthly feed use efficiency report and each farm's environmental impact is updated annually, which results in an unusually rich and accurate source of both management and environmental impact data.

Woodlands Dairy draws milk from the southern portion of the Sarah Baartman District Municipality, the area between the Storms River in the west and the Great Fish River in the east (Fig. 1). On the coast, forage production is mainly rain-fed with occasional irrigation from ground and surface water. Further inland, along the Great Fish River, it is fully irrigated. In both areas dairy production is pasture based, with purchased concentrates and some supplementary purchased roughage. The main dairy breeds are Holstein Friesians and Jerseys or cross breed herds of these two types. The typical farm is family owned and operated, with an average of 793 cows in milk and an annual milk turnover of ZAR 24.4 million. Feed costs account for $70 \%$ of farm expenses. The coefficients of variation in Table 1 indicate that most farms in the group are close to best practice on cow nutrition and less so on hay production. Profit margins have been under pressure for a while, resulting in many business failures in recent times, with the number of dairy farms reducing from 407 in January 2008 to 256 in August 2015 (MPO, 2015).

The dataset contains 80 observations collected from 43 farms in the period since January 2012, the inception date of the Sustainability Project. These data represent all participants in this voluntary programme that raise heifers on the milking farm. Biased towards the behaviour of first movers, the results presented here

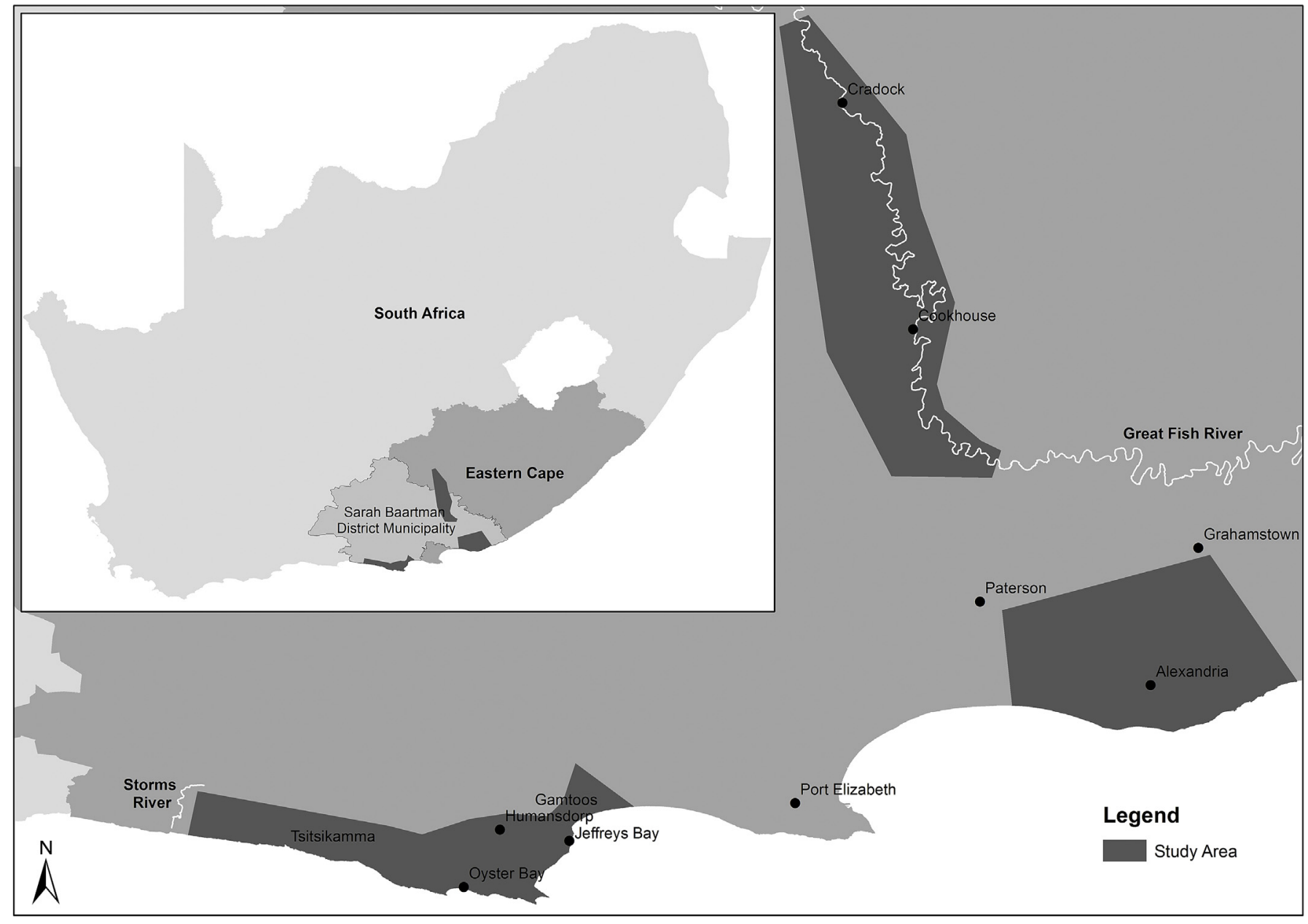

Fig. 1. Location of the study area. 
Table 1

Selected descriptive statistics $(\mathrm{n}=80)$.

\begin{tabular}{|c|c|c|c|}
\hline Variable & Definition and units & Mean & $\mathrm{CV}$ \\
\hline Output & Tons of energy corrected milk & 5,398 & 0.55 \\
\hline Land & Milking platform in hectares & 396 & 0.56 \\
\hline Fertilizer & Expense in ZAR millions & 1.497 & 0.91 \\
\hline Feed & Roughage and concentrates in million MJ & 32.576 & 0.55 \\
\hline Herd size & Average cows in milk per month & 793 & 0.52 \\
\hline$\%$ irrigated & Irrigated area/total milking platform & 39 & 0.84 \\
\hline Stocking density & Cows in milk per hectare & 2.23 & 0.49 \\
\hline$\%$ concentrates & $\%$ of feed expense on concentrates & 78 & 0.21 \\
\hline Rainfall & In millimetres per year & 748 & 0.36 \\
\hline Soil carbon & $\%$ & 2.96 & 0.54 \\
\hline Nutrient efficiency & $\%$, composite measure & 27 & 0.43 \\
\hline GHG emissions & $\mathrm{kg} \mathrm{CO} 2$ emissions per $\mathrm{kg}$ of energy corrected milk & 1.49 & 0.17 \\
\hline
\end{tabular}

$\mathrm{CV}=$ coefficient of variation $=$ standard deviation/sample mean.

are therefore not fully representative of the industry although they still provide valuable insight into the adoption of best practice. The years were pooled for the analysis.

\subsection{Determining firm efficiency}

Firm efficiency is calculated with data envelopment analysis, a linear programming algorithm that fits a piece-wise linear shell of best practice around a sample of input and output data. For a production function $F$ with firm level inputs $x$ and output $y$ let

$F\left(y_{i}, x_{i}\right)=\min \left[\lambda_{i}: \lambda_{i} x_{i} \varepsilon: L^{+}(y)\right]$

where $\lambda_{i}$ are the set of firm level efficiency scores by which firms are arranged so that input use is minimized. The Coelli (1996) software, DEAP 2.1, implements the Banker et al. (1984) variable returns to scale model with the following linear programming problem:

$T\left(y_{i}, x_{i}\right)=\min \lambda$

subject to $z y=y_{i}$

$z x \leq \lambda_{i} x_{i}$

$z \geq 0$

$\sum z_{i}=1$

where $T(\cdot)$ is the data envelopment dual linear programming problem to be solved for firm $z$.

Fare et al. (1985) decomposed overall efficiency into pure technical and scale efficiency with scale efficiency defined as a firm's technical efficiency score under the assumption of constant returns to scale divided by its technical efficiency score under the assumption of variable returns to scale.

Balcombe et al. (2006) constructed a dairy production frontier with purchased feed, herd size, irrigated area and fertilizer as inputs and milk production as output. This formulation supposes a degree of substitutability between farm-grown and purchased fodder, with the latter treated as land enhancing input alongside fertilizer. This aspect of production is treated as functionally separable from the other important decision that dairy farmers face, namely how to combine labour and labour enhancing inputs (machinery), neither of which was available in the dataset.

Output was energy corrected milk production, with the latter correcting raw litres for butterfat and protein percentages to reflect the impact of these variables on the farm-level milk price, as is standard in the carbon footprint literature (Rotz et al., 2010; Kristensen et al., 2011; de Léis et al., 2015). For example, if a farm produces a million litres of milk with an average butterfat of $4 \%$ and an average protein content of $3 \%$, then its energy corrected milk output is litres of milk production $x\{[(0.383 \times$ butterfat $\%)+(0.242 \times$ protein $\%)+0.7832] / 3.14\}$, which is equal to $968,535 \mathrm{~kg}$ of energy corrected milk (Sjaunja et al., 1990). Energy corrected milk production has not been used in the productivity literature, where milk solids are usually included as a second input alongside the raw litres of milk produced (Stokes et al., 2007; Kelly et al., 2012; Mugera, 2013). The average farm in this sample produces approximately 5400 tons of energy corrected milk per year.

The land variable captures the size of the milking platform, an average area of 396 ha which is usually quite close to total farm size. These data were confirmed using ESRI ArcGIS ArcMAP 10.2.2.

The quantity of fertilizer applied is regularly monitored by Trace \& Save. Rand values for fertilizer were calculated per nutrient applied, based on the average cost of urea $(\mathrm{N})$, monoammonium phosphate $(\mathrm{P})$ and potassium chloride (K) fertilizer at local outlets in 2015. The cost of chicken litter (ZAR 500 per ton), the most important form of bought organic fertilizer used on farms included in this study, was used to calculate the value of organic sources of $\mathrm{N}, \mathrm{P}$ and $\mathrm{K}$. The mean expenditure on fertilizer was ZAR 3779 per hectare, although it varied more than either output or feed input.

To compute the total metabolic energy of roughage and concentrates, the standard energy content of various feedstocks was applied to Trace \& Save's feed quantity data, using the values published in Bredon et al. (1987).

Although most dairy frontier models include cows in milk as an input, not all do (e.g. Hansson, 2007; Theodoridis and Psychoudakis, 2008; Hansson et al., 2011; Latruffe et al., 2012; Shortall and Barnes, 2013). Herd-size data were available in this dataset, but the variable was not included in the analysis because cows are an intermediate farm produced input. It was retained in the partial productivity analysis to see if cow size and stocking density correlated with total factor productivity. Other factors examined were rainfall and soil quality indicators. Rainfall data were taken from farm records or matched to the nearest official weather station (www.dwa.gov.za/ hydrology/hymain.aspx). Annual soil samples analysed by a LECO $^{\mathbb{R}}$ elemental combustion analyser at Bemlab, a South African National Accreditation System accredited laboratory, provided the soil carbon estimates.

\subsection{Determining the environmental impact}

A carbon footprint assessment (FAO, 2010; Rotz et al., 2010; Kristensen et al., 2011) is conducted once a year for each farm in 
the sample. Only scope 1 - direct greenhouse gas emissions from company owned or controlled sources - and scope 2 - indirect greenhouse gas emissions from purchased energy - emissions were considered as they are the only types of emissions for which accurate data were available and they are considered the most important. Scope 1 covers emissions from fuel use, enteric fermentation, manure management, crop production while scope 2 covers emissions associated with electricity production. The emissions from enteric fermentation and manure management were calculated using the International Panel on Climate Change tier 2 methodology (IPCC, 2006). Emissions from fuel use were calculated on the basis of the United Kingdom's Department of Environment, Food and Rural Affairs emissions factors (DEFRA, 2012) while the local electricity supplier, ESKOM, supplied the electricity emission factors. The emissions from crop production were calculated using the Australian Cool Farm Tool (van Tonder and Hillier, 2014).

A nutrient budget of nitrogen and phosphorous, and a composite of the two, is used by Trace \& Save to measure nutrient emissions over a period of one year (Cichota and Snow, 2009). The nutrient budget was calculated by dividing the total amount of the nutrients (nitrogen and phosphorous) exported as milk and meat by the total amount of nutrients imported onto the farm as feed and fertilizer in a year. The composite measure is a simple addition of the two.

\subsection{Examining the link between productivity and emissions}

Farmers are trained to pay attention to partial rather than overall efficiency measures, because partial measures focus their management efforts on specific aspects of a complex system. Several of these already familiar partial measures were correlated with overall efficiency, including stocking density and feed use per litre of milk produced, alongside the environmental variables already mentioned. For the analysis, the sample was partitioned into terciles according to overall total factor productivity. The top third farms are most efficient, followed by a middling group and the bottom third. A Shapiro-Wilk test conducted in IBM SPSS Statistics 24 , checked for normality to choose between single variable analysis of variance and its non-parametric equivalent the
Kruskal-Wallis test, which was more appropriate in most instances. The Kruskal-Wallis tests were also conducted in SPSS.

\section{Results}

\subsection{Pure technical, scale and overall technical efficiency}

The average farm was $83.0 \%$ efficient in pure technical terms and had a scale efficiency of $94.2 \%$, of which the product is $77.9 \%$, the overall technical efficiency. As explained above, these measures of composite productivity consider all inputs and outputs at the same time, which implicitly allows for different ways of doing dairy production. The degree of substitution investigated in this paper is the movement along the land and land enhancing continuum and the substitution of purchased feed for fertilizer with which to produce one's own roughage. The results indicate that members of the group are within $6 \%$ of being optimally scaled and within $17 \%$ of doing the practices of dairy farming as well as they possibly could. If inefficient firms corrected both types of problems they ought to improve the output for the currently level of input by at most $22 \%$, a modest potential gain.

Some farms perform better than others. Table 2 breaks down the performance by efficiency tercile and Fig. 2 provides the distribution of the pure technical and scale efficiency scores. Overall efficiency in the top group was $94.1 \%$. In the middle group it was only $78.9 \%$ and for the bottom third if fell to $61.9 \%$. Fig. 2 shows that with eight exceptions, the firms in this sample were within $10 \%$ of being scale efficient. The serious outliers include three firms that were too big and five that were too small. The optimal scale of production is approximately 790 cows in milk on a milking platform of 397 total hectares, with 149 ha of irrigated pastures and 248 ha of dryland pastures. Farms that operate below this optimal scale run approximately 645 cows in milk on 321 ha of pasture, while those that operate above the optimal scale have a herd of 1182 cows on about 592 ha.

There was more variation in technical than in scale efficiency and these two elements were uncorrelated with each other (correlation coefficient $[r]=0.09$, level of significance $[\mathrm{p}] \leq 0.41$ ). The $15 \%$ least pure technically efficient firms in the sample were $67.3 \%$ efficient, and since this cohort also included the least scale efficient

Table 2

Selected partial productivity measures, environmental factors and environmental impact measures, grouped by overall efficiency scores.

\begin{tabular}{|c|c|c|c|c|}
\hline \multirow{3}{*}{$\begin{array}{l}\text { Partial productivity measures, environmental factors } \\
\text { and environmental impact measures }\end{array}$} & \multicolumn{3}{|l|}{ Efficiency tercile } & \multirow[t]{3}{*}{ Kruskal-Wallis $\mathrm{H}$} \\
\hline & Upper $(n=27)$ & Middle $(\mathrm{n}=26)$ & Lower $(\mathrm{n}=27)$ & \\
\hline & \multicolumn{3}{|c|}{ Mean \pm std deviation } & \\
\hline Stocking density (CiM/ha) & $2.55 \pm 1.32$ & $2.47 \pm 0.96$ & $1.66 \pm 0.65$ & $10.86^{* *}$ \\
\hline Milk production (kg ECM/cow) & $6,777 \pm 913$ & $6,816 \pm 884$ & $6,444 \pm 987$ & 2.57 \\
\hline Milk production (kg ECM/ha) & $17,189 \pm 8,265$ & $16,428 \pm 5,620$ & $10,847 \pm 4,834$ & $13.26^{* *}$ \\
\hline Purchased concentrates fed (MJ/kg ECM) & $4.03 \pm 1.00$ & $4.82 \pm 0.68$ & $5.42 \pm 0.98$ & $21.34^{* *}$ \\
\hline Purchased roughage fed (MJ/kg ECM) & $1.49 \pm 1.42$ & $1.22 \pm 1.20$ & $2.10 \pm 2.16$ & 2.85 \\
\hline Fertilizer (R/ha) & $3,031 \pm 2,239$ & $4,361 \pm 2,722$ & $3,711 \pm 2,377$ & 3.41 \\
\hline Fertilizer (R/kg ECM) & $0.17 \pm 0.11$ & $0.27 \pm 0.16$ & $0.33 \pm 0.13$ & $16.79^{* *}$ \\
\hline Fertilizer (kg N/ha) & $209 \pm 137$ & $274 \pm 163$ & $250 \pm 139$ & 1.98 \\
\hline Fertilizer (kg P/ha) & $23 \pm 26$ & $34 \pm 37$ & $19 \pm 28$ & 2.86 \\
\hline Fertilizer (kg K/ha) & $49 \pm 71$ & $98 \pm 85$ & $75 \pm 86$ & $8.05^{*}$ \\
\hline Irrigated area (\%) [ha irrigated/total ha] & $55 \% \pm 33 \%$ & $42 \% \pm 31 \%$ & $19 \% \pm 21 \%$ & $15.80^{* *}$ \\
\hline Annual rainfall $(\mathrm{mm})$ & $714 \pm 310$ & $784 \pm 280$ & $747 \pm 215$ & 1.04 \\
\hline Soil carbon in sand (\%) & $3.17 \% \pm 0.97 \%$ & $3.62 \% \pm 2.03 \%$ & $2.45 \% \pm 1.60 \%$ & $8.34^{*}$ \\
\hline Soil carbon in loam (\%) & $2.37 \% \pm 0.99 \%$ & $3.04 \% \pm 1.49 \%$ & $2.66 \% \pm 0.07 \%$ & 0.18 \\
\hline Composite nutrient use efficiency (\%) & $34 \% \pm 13 \%$ & $26 \% \pm 10 \%$ & $22 \% \pm 9 \%$ & $17.19^{* *}$ \\
\hline GHG emissions ( $\left.\mathrm{kg} \mathrm{CO}_{2} \mathrm{e} / \mathrm{kg} \mathrm{ECM}\right)$ & $1.43 \pm 0.20$ & $1.42 \pm 0.21$ & $1.61 \pm 0.30$ & $8.43^{* *}$ \\
\hline
\end{tabular}

${ }^{* *} \mathrm{p} \leq 0.01$ and ${ }^{*} \mathrm{p} \leq 0.05$. The Upper tercile was $84-100 \%$ efficient, the Middle tercile was $73-84 \%$ efficient and the Lower tercile 3 was $25-73 \%$ efficient. 


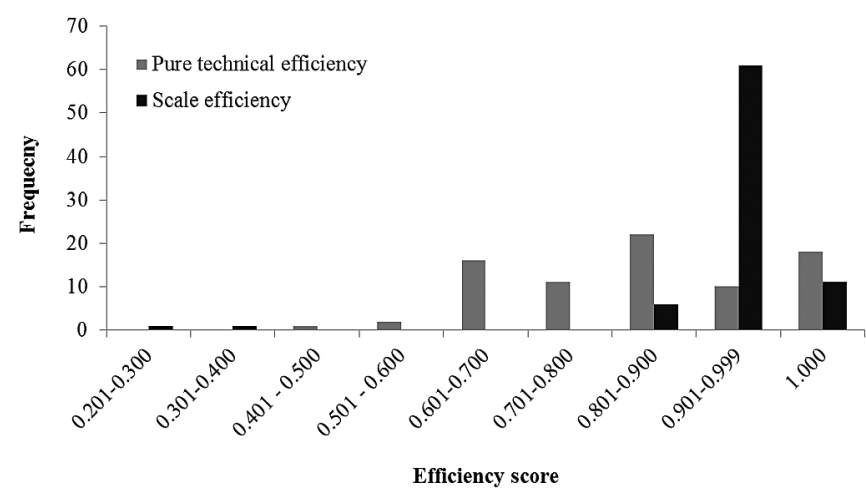

Fig. 2. Distribution of the pure technical and scale efficiency scores $(n=80)$.

firms, their overall efficiency score was just 53.1\%. In theory these firms should be able to almost double output with current inputs, at no further cost to the environment.

\subsection{A comparison of partial and total factor productivity measures}

The two partial productivity measures that varied with overall efficiency were stocking density measured as cows in milk per hectare $(p \leq 0.00)$ and milk production measured in kilograms of energy corrected milk per hectare $(p \leq 0.00)$. These variables were highly correlated with each other $(\mathrm{r}=0.97, \mathrm{p} \leq 0.00)$ and with overall productivity (herd size: $\mathrm{r}=0.38, \mathrm{p} \leq 0.00$; milk produced per hectare of the milking platform: $\mathrm{r}=0.42, \mathrm{p} \leq 0.00$ ). This was to be expected, since both land and milk were used to calculate the frontier and resulting efficiencies. In addition, efficiency was found to be enhanced by greater access to irrigation ( $r=0.47, \mathrm{p} \leq 0.00$ ).

The difference in the amount of concentrates fed, measured in mega joules of energy per kilogram of energy-corrected milk produced, was significant across the terciles $(\mathrm{p} \leq 0.00)$. A significant negative correlation was also found between concentrates fed and overall efficiency ( $r=-0.56, p \leq 0.00$ ). Unlike concentrate use, the roughage fed per kilogram of energy-corrected milk produced was not significantly different across terciles. The least efficient producers have the lowest feed conversion, which means that they feed the largest quantity of concentrates and roughage per kilogram of energy-corrected milk produced of all three groups.

There was no difference across the efficiency terciles in terms of the total cost of fertilizer, or the kilograms of nitrogen, phosphorus and potassium fertilizer applied per hectare. The fertilizer application per kilogram of energy-corrected milk produced, differed between the terciles ( $\mathrm{p} \leq 0.00$ ), and was also negatively correlated with efficiency $(r=-0.46, p \leq 0.00)$.

\subsection{Relating measures of environmental impact to overall technical efficiency}

Significant differences were found between the efficiency terciles in terms of nutrient use efficiency ( $p \leq 0.00$ ), with the upper tercile displaying the highest efficiency. Both overall technical efficiency and pure technical efficiency correlated positively with the composite nutrient-use-efficiency score (overall technical efficiency: $\mathrm{r}=0.50, \mathrm{p} \leq 0.00$; pure technical efficiency: $\mathrm{r}=0.40$, $\mathrm{p} \leq 0.00)$. Nitrogen use efficiency $(\mathrm{r}=0.51, \mathrm{p} \leq 0.00)$ correlated positively with overall efficiency.

Greenhouse gas emissions per unit of milk production, measured in kilograms of carbon dioxide equivalents per kilogram of energy corrected milk production, showed a negative correlation with overall technical efficiency $(r=-0.37 ; p \leq 0.00)$, indicating fewer emissions per litre of production on more efficient farms. The differences across efficiency terciles were also significant $(p<0.01)$.

\section{Discussion}

This study found little variation in technical efficiency amongst this group of Eastern Cape pasture-based dairy farms. This could be for one of three reasons: methodological issues, extension input or as a result of the industry being subjected to a severe cost price squeeze.

For every dimension added to the production function, there is an extra opportunity to be efficient in that dimension and with every observation added, the chances of a given firm making it onto the frontier is reduced. Consequently, one should be careful not to compare efficiency scores from one study to the next, unless the models and sample sizes involved are comparable. Our model used a similar sized dataset to the one analysed by Mkhabela (2006) and a much simpler model than his six-input affair, which means that our measured efficiencies ought to be lower than his. At a mean overall technical efficiency of $78 \%$, our figure is lower than his $87 \%$, but not as much as one would expect. This provides some evidence that the Trace \& Save Programme is providing useful advice which enhances the performance of the less productive group members. In addition, the industry has experienced falling profitability over the last decade which has made smaller, less efficient operations unviable (MPO, 2015). The result is an industry in which more milk is now produced more competitively by fewer primary producers. Under these conditions it is important to keep technologically up to date, for example by joining a benchmarking club such as Trace \& Save. This insight from this analysis is that once such captive audience has been established it becomes possible to promote more environmentally production methods.

The most efficient farms carry the highest stocking rates and produce the most milk on the available land. This shows that farm productivity is best enhanced by greater intensification of agricultural production on the available land. This strategy carries potential environmental risks though, as intensification increases the risk of point-source pollution, for example nitrates and phosphates causing eutrophication in water sources, and greenhouse gas emissions contributing to climate change (Shortall and Barnes, 2013; Toma et al., 2013). Moreover, increasing agricultural production through expansion threatens biodiversity conservation (Phalan et al., 2011). While point-source pollution is often emphasised in the dairy industry as an environmental risk, Hemme et al. (2014) stress the need for more research on how to manage nutrients within the limits of existing land use. The results of our study show that farms that maximise milk output within current land-use constraints are not only achieving greater economic efficiency, but are also those which have the lowest environmental impact. Thus, on pasture-based dairy farms, sustainability and productivity goals are not mutually exclusive, and can be met through the same practices.

We also found that the amount of milk produced per cow was not significantly correlated with overall efficiency. The breed and size of a cow is the most important factor influencing the milk production per cow, and while the optimum size for a pasturebased cow in South Africa is a much-debated subject in local dairy farming circles, our results suggest that this focus is misplaced. Therefore, it is not necessary to select for cows that produce the most milk per cow.

In a pasture-based system, a cow's nutritional requirement is met through pasture grazing, supplemented with purchased grainbased concentrates and roughage (Hills et al., 2016). Concentrates, which are expensive and subject to large price variations, are used mainly to ensure that the animal receives all the required micro 
nutrients and that its energy requirement is reached. Roughage is also subject to price variation and often needs to be transported long distances, which is costly. The overprovision of concentrates and/or roughage can result in a reduction of intake of pasture by cows. This is known as substitution, and should be avoided, as it causes inefficient pasture utilisation (Hills et al., 2016). Efficiency can thus be improved by saving on concentrates to some degree, but this strategy involves maintaining a fine balance, as too few concentrates could result in lower milk production.

Farms with the highest stocking rate are the most efficient. Although annual rainfall was found to be uncorrelated with efficiency, efficiency increased with the percentage of pasture that is irrigated. While enough pasture growth is important to support a higher stocking density, Dillon (2006) pointed out that the important thing for profit maximisation is not to let available pasture go to waste. The other way in which good pasture management contributes to farm welfare is that, through the timing of rotational grazing, root growth is promoted which sequesters carbon (Conant et al., 2001), which has the ability to mitigate some of the negative effects of greenhouse gas emissions from dairy farming (Rutledge et al., 2015).

Since the amount of milk produced per hectare correlated with efficiency, it was expected that overall fertilizer use would too, but it did not. Fertilizer costs, and N, P and K applied per hectare, were the lowest and highest in the middle and upper efficiency terciles, and fertilizer costs per kilogram of energy corrected milk increased from the upper to lower efficiency tercile. This indicates that the effective use of fertilizer, used to grow productive pastures which are converted into the output, milk production, improves efficiency.

Soil carbon is an important indicator of soil health, as carbon improves the physical properties of soil, which in turn ensures nutrient availability and improves soil biology (Tiessen et al., 1994; Martinez-Salgado et al., 2010; Fageria, 2012). Improved soil biology can contribute to a farm system which has moderate resource inputs, but still results in high productivity (Bender et al., 2016). The potential improvement of soil carbon on soil fertility and water-holding capacity is greater in sandy than loamy soils, since clays have many of the same properties as organic matter. Therefore, the correlation that was found between soil carbon and efficiency on farms with predominantly loamy soils was not expected, whereas it was expected that the relationship be present on the subset of farms dominated by sandy soils. The lack of a significant relationship between soil carbon and efficiency is not easily explained. As mentioned above, effective grazing management has the potential to increase soil carbon levels, but since there was no baseline data on soil carbon levels, this hypothesis had to go untested. Further research is therefore needed to understand the influence of soil health on farm efficiency, and vice versa.

The carbon levels in sand were higher than those in loam, which might point to a concerted effort by farmers to build organic matter in their soils as had in fact been done by the field staff of the sustainability project. Recommended practices include minimal tillage, rotational grazing systems and planting multiple plant species in pastures (Conant et al., 2001; Sanderman et al., 2013; Badgery et al., 2014; Rutledge et al., 2015).

Carbon footprint analysis has become broadly accepted as an assessment of the negative environmental impact of an entity in relation to greenhouse gas emissions and this includes the dairy industry (Shortall and Barnes, 2013; Toma et al., 2013). When considering a farm's carbon footprint, arguably the most important aspect to measure is the emission of carbon dioxide equivalents per relative milk production, as this measure allows for productionfocussed comparisons between different management systems.
The results indicate that the more efficient farms are characterised by lower emissions per unit of production.

Nutrient balance sheets are used to calculate the total quantity of nutrients imported onto the farm as fertilizer and feed and the total quantity of nutrients removed as milk. While originally devised as a cost management tool (Spears et al., 2003) they are now often used to monitor environmental impact (Reinhard et al., 2000; Cichota and Snow, 2009). The inputs and outputs are very similar to those used in data envelopment analysis, therefore the outcomes were expected to be correlated. By including the nutrient budget analysis in this paper, a connection was made between a commonly accepted agricultural economic assessment of efficiency and an accepted assessment of agricultural impact on the environment. Although this has been done in previous studies on dairy farms by Reinhard et al. (2000), Ramilian et al. (2011) and Toma et al. (2013), these researchers included proxies for the environmental impact factors directly in the frontier, and not to explain deviations from the frontier as was done here. Opposite to our study, Ramilian et al. (2011) concluded that lowering stocking rates and selecting higher producing cows could improve environmental efficiency. Although not a finding of their study, they did identify reduced external nitrogen inputs as a mechanism to reduce nitrogen discharge, which we found to be true in our study. Toma et al. (2013) compared genetic divergence between contrasting management systems and concluded that genetic differences and herd health are a main driver of efficiency. Similar to our study, they found inputs to influence environmental efficiency.

\section{Conclusion}

We investigated whether a pursuit of economic efficiency in dairy production had an adverse bearing on the environment. A high overall efficiency was observed on many fully efficient farms, although most farms could still improve. This study found that the cost-drive influencing the high efficiencies on the farms, i.e. the efficient use of fertilizer and bought feed, as well as the maximum utilisation of the available land, all set up by a highly competitive market, was beneficial for the environment. Sustainability and productivity goals can be met through the same practices on pasture-based dairy farms.

An important area to improve on is the practice of optimising stocking rate in order to maximise the utilisation of pasture growth (Dillon, 2006; Hills et al., 2016). The least efficient farms in this study appeared to be under-stocked, and thus produce the lowest amount of milk per unit of land. Another opportunity for improving efficiency is to increase milk production per unit of concentrates fed. The measure "grams of concentrates fed per litre of milk produced" is widely adopted by dairy farmers as an indicator of efficiency, and this study confirms the usefulness of such a measure. Climate and soil type did not appear to have a significant effect on the technical efficiency of the farms studied, indicating that these environmental factors should not be a limiting factor in managing an efficient dairy farm in the study area. These insights into how pasture-based dairy farmers can achieve greater total factor productivity on their farms can inform the practices of not only farmers, but also those of consultants and researchers.

Further research should determine practices that most influence technical efficiency, but because dairy farming systems are complex and vary between geographic areas, this is a challenging task. This study has provided some groundwork, by identifying areas of opportunity for a group of dairy farmers to improve efficiency, and thereby the sustainability of their farming system. Further research should also go into exploring how labour and capital productivity interact with land productivity. 


\section{Acknowledgements}

Our thanks to Phillip and Marlene Terblanche, owners of the Trace \& Save Programme, who provided intellectual guidance, support and insight into the dairy industry and to Portia Phohlo and Marno Fourie for assistance with data collection.

This work was financially supported by Woodlands Dairy and Trace \& Save.

\section{References}

Badgery, W.B., Simmons, A.T., Murphy, B.W., Rawson, A., Andersson, K.O., Lonergan, V.E., 2014. The influence of land use and management on soil carbon levels for crop-pasture systems in Central New South Wales, Australia. Agric. Ecosyst. Environ. 196, 147-157.

Balcombe, K., Fraser, I., Kim, J.H., 2006. Estimating technical efficiency of Australian dairy farms using alternative frontier methodologies. Appl. Econ. 38, $2221-2236$.

Banker, R.D., Charnes, A., Cooper, W.W., 1984. Some models for estimating technical and scale inefficiencies in data envelopment analysis. Manag. Sci. 30, 1078-1092.

Battese, G.E., Coelli, T.J., 1995. A model for technical inefficiency effects in a stochastic frontier production function for panel data. Empir. Econ. 20, 325-332.

Bender, S.F., Wagg, C., van der Heijden, M.G., 2016. An underground revolution: biodiversity and soil ecological engineering for agricultural sustainability. Trends Ecol. Evol. 31 (6), 440-452.

Bezlepkina, I., Reidsma, P., Sieber, S., Helming, K., 2011. Integrated assessment of sustainability of agricultural systems and land use: methods, tools and applications. Agric. Syst. 104, 105-109.

Bredon, R.M., Stewart, P.G., Dugmore, T.J., 1987. A Manual on the Nutritive Value and Chemical Composition of Commonly Used South African Farm Feeds. Natal Region, Department of Agriculture and Water Affairs, South Africa.

Cichota, R., Snow, V.O., 2009. Estimating nutrient loss to waterways- an overview of models of relevance to New Zealand pastoral farms. N. Z. J. Agric. Res. 52 (3), 239-260.

Coelli, T.J., Presada Rao, D.S., O'Donnell, C.J., Battese, G.E., 2005. An Introduction to Efficiency and Productivity Analysis, second ed. Springer Science \& Business Media.

Coelli, T.J., 1996. A Guide to DEAP Version 2.1.: a Data Envelopment Analysis (Computer) Programme. CEPA Working Papers 96/08. Department of Econometrics, University of New England, Armidale, NSW, Australia.

Conant, R.T., Paustian, K., Elliott, E.T., 2001. Grassland management and conversion into grassland: effects on soil carbon. Ecol. Appl. 11 (2), 343-355.

de Léis, C.M., Cherubini, E., Ruviaro, C.F., Da Silva, V.P., do Nascimento Lampert, V., Spies, A., Soares, S.R., 2015. Carbon footprint of milk production in Brazil: a comparative case study. Int. J. Life Cycle Assess. 20 (1), 46-60.

Department of Environment, Food and Rural Affairs (DEFRA), Department of Energy and Climate Change (DECC), 2012. Guidelines to DEFRA/DECC's GHG Conversion Factors for Company Reporting.

Dillon, P., 2006. Achieving high dry-matter intake from pasture with grazing dairy cows. In: Elgersma, A., Dijkstra, J., Tamminga, S. (Eds.), Fresh Herbage for Dairy Cattle, vol. 18, pp. 1-26.

Ernst, T., Wallace, G.N., 2008. Characteristics, motivations, and management actions of landowners engaged in private land conservation in Larimer County Colorado. Nat. Areas J. 28 (2), 109-120.

Fageria, N.K., 2012. Role of soil organic matter in maintaining sustainability of cropping systems. Commun. Soil Sci. Plant Anal. 43, 2063-2113.

Fare, R., Grosskopf, S., Lovell, C.A.K., 1985. The Measurement of Efficiency of Production. Kluwer Nijho Publishing, Boston, USA.

Food and Agriculture Organization of the United Nations (FAO), 2010. Greenhouse Gas Emissions from the Dairy Sector. A Life Cycle Assessment (Report: Animal Production and Health Division).

Hadley, D., 2006. Patterns in technical efficiency and technical change at the farmlevel in England and Wales, 1982-2002. J. Agric. Econ. 57, 81-100.

Hansson, H., 2007. Strategy factors as drivers and restraints on dairy farm performance: evidence from Sweden. Agric. Syst. 94, 726-737.

Hansson, H., Szczensa-Rundberg, M., Nielsen, C., 2011. Which preventive measures against mastitis can increase the technical efficiency of dairy farms? Animal 5 (4), 632-640.

Hemme, T., Uddin, M.M., Ndambi, O.A., 2014. Benchmarking cost of milk production in 46 countries. J. Rev. Glob. Econ. 3, 254-270.

Hills, J.L., Rawnsley, R.P., Harrison, M.T. Bishop-Hurley, G.J., Henry, D.A., Raedts, P., Freeman, M., Roche, D., 2016. Precision feeding and grazing management for temperate pasture-based dairy systems. In: Conference on Precision Dairy Farming, pp. 25-31.

International Panel on Climate Change (IPCC), 2006. Guidelines for National
Greenhouse Gas Inventories. Chapter 10: Emissions from Livestock and Manure Management. Volume 4: Agriculture, Forestry and Other Land Use.

Iribarren, D., Hospido, A., Moreira, M.T., Feijoo, G., 2011. Benchmarking environmental and operational parameters through eco-efficiency criteria for dairy farms. Sci. Total Environ. 409, 1786-1798.

Kelly, E., Shalloo, L., Geary, U., Kinsella, A., Wallace, M., 2012. Application of data envelopment analysis to measure technical efficiency on a sample of Irish dairy farms. Ir. J. Agric. Food Res. 51 (1), 63-77.

Kristensen, T., Mogensen, L., Knudsen, M.T., Hermansen, J.E., 2011. Effect of production system and farming strategy on greenhouse gas emissions from commercial dairy farms in a life cycle approach. Livest. Sci. 140 (1), 136-148.

Latruffe, L., Fogarasi, J., Desjeux, Y., 2012. Efficiency, productivity and technology comparison for farms in Central and Western Europe: the case of field crop and dairy farming in Hungary and France. Econ. Syst. 36, 264-278.

Martinez-Salgado, M.M., Gutierrez-Romero, V., Jannsens, M., Ortega-Blu, R., 2010. Biological soil quality indicators: a review. In: Mendez-Vilas (Ed.), Current Research, Technology and Education Topics in Applied Microbiology and Microbial Biotechnology. Formatex, pp. 319-328.

Mayberry, D., Crase, L., Gullifer, C., 2005. Categorising farming values as economic, conservation and lifestyle. J. Econ. Psychol. 26, 59-72.

McGuire, J., Morton, L.W., Cast, A.D., 2013. Reconstructing the good farmer identity: shifts in farmer identities and farm management practices to improve water quality. Agric. Hum. Values 30, 57-69.

Mkhabela, T.S., 2006. Technical efficiency estimates for the Kwazulu-Natal midlands dairy industry. J. Stud. Econ. Econ. 30 (1), 129-145.

MPO (Milk Producers Organization), 2015. Lacto data. Stat. A Milk SA Publ. Compil. Milk Prod. Organ. 18 (2).

Mugera, A.W., 2013. Measuring technical efficiency of dairy farms with imprecise data: a fuzzy data envelopment analysis approach. Aust. J. Agric. Resour. Econ. 57, 501-519.

Phalan, B., Onial, M., Balmford, A., Green, R.E., 2011. Reconciling food production and biodiversity conservation: land sharing and land sparing compared. Science 333, 1289-1291.

Ramilian, T., Scrimgeour, F., Marsh, D., 2011. Analysis of environmental and economic efficiency using a farm population micro-simulation model. Math. Comput. Simul. 81, 1344-1352.

Reinhard, S., Lovell, C.K., Thijssen, G.J., 1999. Econometric estimation of technical and environmental efficiency: an application to Dutch dairy farms. Am. J. Agric. Econ. 81 (1), 44-60.

Reinhard, S., Lovell, C.K., Thijssen, G.J., 2000. Environmental efficiency with multiple environmentally detrimental variables; estimated with SFA and DEA. Eur. J. Operat. Res. 121, 287-303.

Rigby, D., Woodhouse, P., Young, T., Burton, M., 2001. Constructing a farm level indicator of sustainable agricultural practice. Ecol. Econ. 39, 463-478.

Rotz, C.A., Montes, F., Chianese, D.S., 2010. The carbon footprint of dairy production systems through partial life cycle assessment. J. dairy Sci. 93 (3), 1266-1282.

Rutledge, S., Mudge, P.L., Campbell, D.I., Woodward, S.L., Goodrich, J.P., Wall, A.M., Kirschbaum, M.U., Schipper, L.A., 2015. Carbon balance of an intensively grazed temperate dairy pasture over four years. Agric. Ecosyst. Environ. 206, 10-20.

Salazar-Ordonez, M., Rodriguez-Entrena, M., Sayadi, S., 2013. Agricultural sustainability from a societal view: an analysis of southern Spanish citizens. J. Agric. Environ. Ethics 26, 473-490.

Sanderman, J., Fillery, I.R., Jongepier, R., Massalsky, A., Roper, M.M., Macdonald, L.M., Maddern, T., Murphy, D.V., Wilson, B.R., Baldock, J.A., 2013. Carbon sequestration under subtropical perennial pastures I: overall trends. Soil Res. 51 (8), $760-770$.

Shortall, O.K., Barnes, A.P., 2013. Greenhouse gas emissions and the technical efficiency of dairy farmers. Ecol. Indic. 29, 478-488.

Sjaunja, L.O., Baevre, L., Junkkarinen, L., Pedersen, J., Setälä, J., 1990. A Nordic Proposal for an Energy Corrected Milk (ECM) Formula. 27th Session. ICRPMA, Paris. July 2-6, 1990.

Spears, R.A., Kohn, R.A., Young, A.J., 2003. Whole-farm nitrogen balance on western dairy farms. J. Dairy Sci. 86, 4178-4186.

Stokes, J.R., Tozer, P.R., Hyde, J., 2007. Identifying efficient dairy producers using data envelopment analysis. J. Dairy Sci. 90 (5), 2555-2562.

Theodoridis, A.M., Psychoudakis, A., 2008. Efficiency measurement in Greek dairy farms: stochastic frontier vs. data envelopment analysis. Int. J. Econ. Sci. Appl. Res. 1 (2), 53-67.

Tiessen, H., Cuevas, E., Chacon, P., 1994. The role of soil organic matter in sustaining soil fertility. Nature 371 (6500), 783-785.

Toma, L., March, M., Stott, A.W., Roberts, D.J., 2013. Environmental efficiency alternative dairy systems: a productive efficiency approach. J. Dairy Sci. 96, 7014-7031.

Van Calker, K.J., Berentsen, P.B.M., Giesen, G.W.J., Huirne, R.B.M., 2005. Identifying and ranking attributes that determine sustainability in Dutch dairy farming. Agric. Hum. Values 22, 53-63.

van Tonder, C., Hillier, J., 2014. Cool Farm Tool. Technical Documentation for the Online Cool Farm Tool. Cool Farm Alliance. 